\title{
Effects of Sauropus androgynus extract and its combination with ampicillin against Methicillin-resistant Staphylococcus aureus: An in vitro study
}

\author{
Asih Rahayu1(D), Chylen Setiyo Rini² (D), Yos Adi Prakoso1(D), Bagus Uda Palgunadi1(i) and Muhammad Aris Munandar² (i) \\ 1. Faculty of Veterinary Medicine, University of Wijaya Kusuma Surabaya, East Java, Indonesia; 2. Integrated Laboratory, \\ Faculty of Health, University of Muhammadiyah Sidoarjo, East Java, Indonesia. \\ Corresponding author: Bagus Uda Palgunadi, e-mail: bagusuda24@gmail.com \\ Co-authors: AR: asihrhy24@gmail.com, CSR: chylensetiyorini@umsida.ac.id, YAP: yos.vet.docter@gmail.com, \\ MAM: arismurf95@gmail.com \\ Received: 23-04-2020, Accepted: 22-07-2020, Published online: 14-09-2020
}

doi: www.doi.org/10.14202/IJOH.2020.128-133 How to cite this article: Rahayu A, Rini CS, Prakoso YA, Palgunadi BU, Munandar MA (2020) Effects of Sauropus androgynus extract and its combination with ampicillin against Methicillinresistant Staphylococcus aureus: An in vitro study, Int. J. One Health, 6(2): 128-133.

\begin{abstract}
Background and Aim: The massive utilization of antibiotics has increased resistant genes produced by bacteria. Many bacteria, including Methicillin-resistant Staphylococcus aureus (MRSA), have become resistant against ampicillin (AMP). The combination of an herbal extract with AMP is expected to generate synergistic effects and may restore the susceptibility of MRSA against AMP. This study aimed to analyze the potency of Sauropus androgynous extract (SAE) as a single extract and combination with AMP against MRSA.
\end{abstract}

Materials and Methods: Sauropus androgynous was extracted using 60\% ethanol. SAE biochemical compounds were analyzed qualitatively and quantitatively. SAE, AMP, and SAE+AMP were tested against MRSA isolates to determine the minimum inhibitory concentration and fractional inhibitory concentration. The inhibition of penicillin-binding proteins 2a (PBP2a) was analyzed using a latex agglutination test. Further, the disruptive membrane effects of SAE, AMP, and $\mathrm{SAE}+\mathrm{AMP}$ were analyzed using a scanning electron microscope. The analysis of data was conducted using SPSS version 16 with $\mathrm{p}=0.01$.

Results: SAE contained bioactive compounds such as phenolics and flavonoids. Further, $2 \mathrm{mg} / \mathrm{mL}$ of SAE could be used as the potential concentration against MRSA isolates in vitro. In addition, the utilization of SAE+AMP generated synergistic effects, restored the susceptibility of isolates against AMP, decreased the synthesis of PBP2a by the MRSA, and induced ultrastructural changes in the bacterial membrane.

Conclusion: This study indicated that the utilization of SAE potentially inhibits the growth of MRSA through decreasing of PBP2a expression, disruption of the MRSA membrane, while the combination of SAE+AMP showed synergistic effects against MRSA.

Keywords: ampicillin, herbal extract, Methicillin-resistant Staphylococcus aureus, Sauropus androgynus, ultrastructure.

\section{Introduction}

Antibiotics have been developed massively since they were first discovered in the late $19^{\text {th }}$ century. From a positive standpoint, a large number of antibiotic derivatives are currently available for the treatment of many bacterial species causing infections. However, the development of antibiotics has also influenced the formation of a resistant gene among the microbes [1]. Resistance to the new antibiotics commonly occurs within 2-3 years after they are first utilized as therapeutic agents [2].

Furthermore, antimicrobial resistance (AMR) has spread widely over the world and has become a global concern. Many strategies have been developed

Copyright: Rahayu, et al. This article is an open access article distributed under the terms of the Creative Commons Attribution 4.0 International License (http://creativecommons.org/licenses/ by/4.0/), which permits unrestricted use, distribution, and reproduction in any medium, provided you give appropriate credit to the original author(s) and the source, provide a link to the Creative Commons license, and indicate if changes were made. The Creative Commons Public Domain Dedication waiver (http:// creativecommons.org/ publicdomain/zero/1.0/) applies to the data made available in this article, unless otherwise stated. by scientists, microbiologists, and clinicians to control the resistance phenomenon. One important strategy is the utilization of a combination drug [3]. Antibiotic combinations to treat an infection are often practiced for many reasons, including to broaden the antimicrobial spectrum and to prevent polymicrobial infection, and are expected to generate synergistic effects [4].

An extended-spectrum antibiotic is ampicillin (AMP). AMP is an active antibacterial agent against Gram-positive as well as Gram-negative bacteria [5]. Clinicians generally use AMP to treat many types of infection, including soft tissue and skin infections [6]. However, several species of bacteria affecting the skin have been transforming a resistant gene against AMP. Methicillin-resistant Staphylococcus aureus (MRSA) is a resistant bacterium against AMP through the synthesis of penicillin-binding proteins (PBPs) [7]. A previous study described that the combination of AMP and Coptis chinensis extract may have synergistic effects on inhibiting MRSA colonization because of its berberine content [8]. Another study reported that Acalypha wilkesiana extract exerts a 
synergistic effect when combined with AMP to inhibit MRSA colonization and restores MRSA susceptibility to AMP [9]. This shows that herbal extracts have potential effects of increasing the potency of synthetic antimicrobial agents, especially AMP. Further, the utilization of herbal extracts is expected to promote healing during bacterial infection without promoting resistant genes of these bacteria.

A traditional Indonesian herbal extract is Sauropus androgynus (SA). This herbal preparation contains several bioactive compounds such as alkaloids, tannins, saponins, and flavonoids that can be used as antibacterial agents as well as antioxidants [10]. A previous study elucidated that the SA extract (SAE) could be utilized as an antifungal agent [11]. As an antibacterial agent, SAE can potentially inhibit the growth of Gram-negative bacteria, including Edwardsiella tarda, Escherichia coli, Pseudomonas aeruginosa, Vibrio spp., and Aeromonas hydrophila [12]. Another study showed that SAE promoted wound healing on the wound in a diabetic mouse model infected with MRSA both as a single and combination treatment [13].

Those potencies are caused by the antioxidant activity of SAE activating the healing promoter. However, these previous studies have not explored the potency of SAE in promoting AMP effects against MRSA. Based on this background, this study aimed to explore the potency of SAE against MRSA through the observation of its effects as a single treatment and in combination with AMP.

\section{Materials and Methods}

\section{Ethical approval}

The ethical approval was not applicable because of no animal or human experimentation in this study.

\section{Study location and period}

All the research procedures were carried out in the Integrated Laboratory, Faculty of Health, University of Muhammadiyah Sidoarjo, East Java, Indonesia. The study was conducted from April to October 2019. Further, the scanning electron microscope (SEM) examination was conducted in the Biological Research Center, Indonesian Institute of Sciences, Bogor, Indonesia.

\section{Extract preparation}

SA leaves were purchased from a local botanical garden, Mojokerto, East Java, Indonesia. The plant species was authenticated by a botanist at the Indonesian Institute of Sciences, Purwodadi, Indonesia, with voucher specimen: 0277/IPH.06.HM/II/2019. The SA was dried in an oven (Memmert UN30, custom tariff number 84198998 , Germany) for an hour at $80^{\circ} \mathrm{C}$. The dried SA was pulverized using an electric blender (Waring, MX100XTS, Indonesia). The SA powder was soaked using $60 \%$ ethanol $(50 \mathrm{~g} / 1 \mathrm{~L})$ and was heated using a microwave (Toshiba, EM245A5C-BS, Japan) with $110^{\circ} \mathrm{C}, 1250 \mathrm{~W}$, for $10 \mathrm{~min}$. Next, the SA extract (SAE) was filtered through Whatman filter paper number 4 (Whatman, catalog number 1441090, United States) and was dried at $40^{\circ} \mathrm{C}$ using a rotary evaporator (Buchi, catalog number 6.268.005, Switzerland) to remove residual ethanol [14].

\section{Phytochemical screening}

SAE was tested to determine levels of biochemical compounds, including alkaloids, flavonoids, glycosides, phenolics, saponins, and tannins. The biochemical compounds of SAE were screened using qualitative and quantitative methods. Qualitative tests were performed using the following methods: The Mayer test for alkaloids, magnesium+hydrogen chloride+ethanol test for flavonoids, Borntrager's test for glycosides, $10 \%$ natrium chloride $+1 \%$ gelatin for phenolics, saponins detected by the presence of foams, and tannins were detected using 1\% ferric chloride. Quantitative phytochemical screening was tested in triplicate repetitions. Both qualitative and quantitative tests were performed in accordance with a previous study [15].

\section{Bacterial strain}

The MRSA isolate was obtained from the American Type Culture Collection (ATCC) encoded (ATCC ${ }^{\circledR}$ BAA-29213) and from a clinical isolate from the Department of Microbiology, Faculty of Medicine, University of Airlangga encoded: 53/UN3.1.1/MK/ LL/2019. The stability of bacterial characterization was reconfirmed using several tests, including coagulase, DNase, hemolysis, colony pigmentation, alkaline phosphatase, urease, mannitol, maltose, esculin hydrolysis, novobiocin, polymyxin B, and cefoxitin. The MRSA isolate was stocked in Todd Hewitt agar (Merck, cata$\log$ number 146598, Germany) for further research.

\section{Minimum inhibitory concentration (MIC) test}

The MIC determinations of AMP(Sigma-Aldrich) and SAE against MRSA were conducted according to the methods used in a previous study [16]. The $0.1 \mathrm{~mL}$ of MRSA suspension $\left(5 \times 10^{5} \mathrm{CFU} / \mathrm{mL}\right)$ was added to $0.9 \mathrm{~mL}$ of Mueller-Hinton broth (Merck, catalog number 1.10293.0500, Germany). Further, SAE, AMP, and SAE+AMP were diluted using sterile distilled water to obtain stock solutions of $1024 \mu \mathrm{g} / \mathrm{mL}$ (AMP) and $1024 \mathrm{mg} / \mathrm{mL}$ (SAE). The antibiotic and extract stock solution was serially diluted 3 -fold to achieve respective treatment concentrations. The bacterial suspension was added to SAE, AMP, and SAE+AMP solution and was incubated at $37^{\circ} \mathrm{C}$ for $18 \mathrm{~h}$. The lowest concentration that indicated no visible bacterial growth after incubation was recorded as the MIC.

\section{Checkerboard synergy test}

The synergistic effects of SAE+AMP against the MRSA isolates were tested using the checkerboard synergy test, which was performed similarly to that described above to determine the MIC. However, the SAE+AMP condition was combined and incubated at $37^{\circ} \mathrm{C}$ for $18 \mathrm{~h}$. The lowest concentration of $\mathrm{SAE}+\mathrm{AMP}$ combination that had the potential to 
inhibit bacterial growth was defined as the MIC. The fractional inhibitory concentrations (FICs) of SAE and AMP were used to determine the FIC index (FICI) using the following formulae:

$$
\begin{aligned}
\mathrm{FIC}_{\mathrm{A}}= & \frac{\mathrm{FICI}=\mathrm{FIC}_{\mathrm{A}}+\mathrm{FIC}_{\mathrm{B}}}{\text { MICA after combination }} \\
\mathrm{FIC}_{\mathrm{B}}= & \frac{\text { MICB after combination }}{\text { MICB alone }}
\end{aligned}
$$

The combination of SAE+AMP was classified as synergistic when the FICI was $\leq 0.5$; no interaction when FICI was $>0.5 \leq 2$; and antagonistic when FICI was $\geq 2$ [17].

\section{PBP2a latex agglutination test}

PBP2a latex agglutination test using MRSA biofilm was analyzed semi-quantitatively as follows: (absence); + (weak); ++ (moderate); and +++ (strong). All the test protocols were conducted following the method described in product protocols (PBP2, Oxoid, Latex Agglutination Test, DR0900).

\section{SEM}

The disruptive effects of SAE, AMP, and SAE + AMP on the MRSA membrane were analyzed using an SEM. SEM was conducted in accordance with the MIC. After the incubation, the bacterial suspension was centrifuged (Scilogex, SC1412S, United States) at $1500 \mathrm{rpm}$ for $5 \mathrm{~min}$. Further, 2\% of glutaraldehyde was added and incubated for $3 \mathrm{~h}$, and it was replaced with $2 \%$ of tannin acid and incubated for $6 \mathrm{~h}$. Graded alcohol was used as a dehydrated reagent. The bacteria were then coated with gold and carbon using a sputter coater. The ultrastructure of the MRSA membrane was analyzed using SEM (JEOL NeoScope, JSM5000, Japan), and the diameter and area of the membrane were measured using Image $J$ software (NIH Public Domain, BSD-2, United States).

\section{Statistical analysis}

The experiments were conducted in triplicate. The collected data were compared using one-way ANOVA followed by Bonferroni's post hoc test for multiple comparisons. The results of the analyses were expressed as mean \pm standard deviation. $\mathrm{p}=0.01$ was considered statistically significant.

\section{Results}

Based on the phytochemical analysis, the ethanolic extract of SA contained alkaloids, flavonoids, glycosides, phenolics, saponins, and tannins. The highest concentration of the biochemical compound of SAE was in the order phenolic $>$ glycoside $>$ flavonoid $>$ alkaloid $>$ saponin $>$ tannin, respectively (Table-1).

Furthermore, the SAE was utilized as the additive agent with AMP for further studies. As single agent therapy against either the MRSA clinical or ATCC isolate, the AMP showed highest resistance profile at $1024 \mu \mathrm{g} / \mathrm{mL}$ (based on the CLSI standard). Further, $\mathrm{SAE}$ at the concentration of $2 \mathrm{mg} / \mathrm{mL}$ was potent against
MRSA isolates in vitro. Surprisingly, the combination of SAE+AMP had increased potency against both MRSA isolates. As shown by the FICI of SAE+AMP was $\leq 0.5$, which indicates a synergistic mechanism of action (Table-2). The results suggested that the increasing level of PBP2a within the MRSA biofilms along with the combination of AMP $(1024 \mu \mathrm{g} / \mathrm{mL})$ as the therapeutic agents in vitro was more effective than the untreated controls. Conversely, the SAE $(2 \mathrm{mg} / \mathrm{mL})$ could inhibit PBP2a formation by MRSA, and the synergistic test showed that SAE+AMP combination decreased PBP2a formation against either the MRSA clinical isolate or the ATCC isolate (Table-3).

The SEM analysis showed that there were no significant differences between the MRSA clinical isolate and the ATCC isolate, in terms of the diameter and membrane area in the untreated group. However, the SAE promoted an increase in diameter of either the clinical $(p=0.01$ or $p \leq 0.01)$ or the ATCC isolate $(p=0.005$ or $p \leq 0.01)$. Similar effects by SAE were observed on the membrane area of the clinical isolate $(\mathrm{p}=0.01$ or $\mathrm{p} \leq 0.01)$ and ATCC isolate $(\mathrm{p}=0.006$ or $\mathrm{p} \leq 0.01)$. In contrast, the AMP generated a decreasing diameter of MRSA $(\mathrm{p} \leq 0.01)$. A similar result was obtained by the combination treatment group $(\mathrm{p} \leq 0.01)$ (Table-4). The ultrastructural representation of the MRSA following the treatment is shown in Figure-1.

\section{Discussion}

Herbal extracts contain several bioactive compounds that can be utilized as antioxidant and antimicrobial agents. Bioactive compounds present in

Table-1: Phytochemical screening of SAE.

\begin{tabular}{lcc}
\hline Parameters & $\begin{array}{c}\text { Qualitative } \\
\text { screening }\end{array}$ & $\begin{array}{c}\text { Quantitative } \\
\text { screening }\end{array}$ \\
\hline Alkaloid & ++ & $10.13 \pm 0.12$ \\
Flavonoid & ++ & $12.16 \pm 0.06$ \\
Glycoside & +++ & $19.18 \pm 0.43$ \\
Phenolic & +++ & $23.88 \pm 0.15$ \\
Saponin & ++ & $9.40 \pm 0.39$ \\
Tannin & + & $3.96 \pm 0.05$ \\
\hline
\end{tabular}

The results of quantitative screening were obtained from three repetitions. $\mathrm{SAE}=$ Sauropus androgynous extract

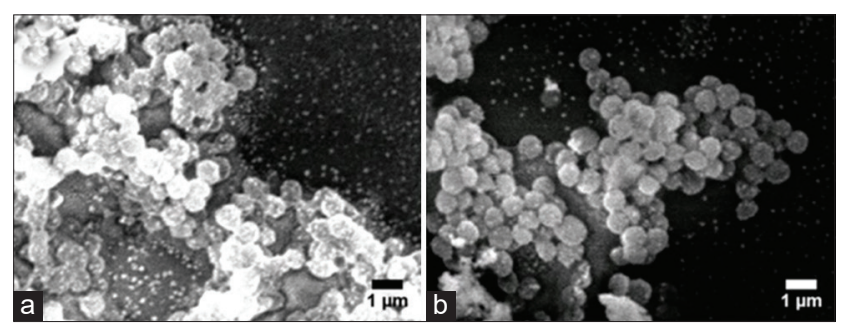

Figure-1: The ultrastructure of MRSA without and with the administration of SAE+AMP. The uniform in size and shape of the MRSA in a group without treatment (a); and the diverse size and shapes of the MRSA after the therapy using a combination of SAE+AMP in vitro (b). JSM5000, SEM, 10,000×. MRSA=Methicillin-resistant Staphylococcus aureus, $\mathrm{SAE}=$ Sauropus androgynus extract, $\mathrm{AMP}=$ Ampicillin. 
Table-2: Potency of SAE, AMP, and SAE+AMP against MRSA.

\begin{tabular}{|c|c|c|c|c|}
\hline \multirow[t]{2}{*}{ Parameters } & \multirow[t]{2}{*}{ Bacterial strain } & \multicolumn{3}{|c|}{ Treatment } \\
\hline & & SAE $(\mathbf{m g} / \mathbf{m L})$ & AMP $(\mu \mathrm{g} / \mathrm{mL})$ & $S A E+A M P(m g / m L+\mu g / m L)$ \\
\hline \multirow[t]{2}{*}{ MIC } & MRSA clinical isolate & $2^{\mathrm{ND}}$ & $1024^{R}$ & $0.5+4$ \\
\hline & ATCC $^{\circledR} 29213$ & $2^{\mathrm{ND}}$ & $1024^{R}$ & $0.5+4$ \\
\hline \multirow[t]{2}{*}{ FICI } & MRSA clinical isolate & NT & NT & $\leq 0.5^{\text {sy }}$ \\
\hline & ATCC $^{\circledR} 29213$ & NT & NT & $\leq 0.5^{\mathrm{Sy}}$ \\
\hline
\end{tabular}

$\mathrm{SAE}=$ Sauropus androgynus extract, $\mathrm{AMP}=$ Ampicillin, $\mathrm{ND}=$ No data provided, $\mathrm{R}=$ Resistant, $\mathrm{N} T=$ Not tested, Sy=Synergistic, MRSA=Methicillin-resistant Staphylococcus aureus

Table-3: Potency of SAE, AMP, and SAE+AMP against the PBP2a of the MRSA.

\begin{tabular}{|c|c|c|c|c|c|}
\hline \multirow[t]{2}{*}{ Parameters } & \multirow[t]{2}{*}{ Bacterial strain } & \multicolumn{4}{|c|}{ Treatment } \\
\hline & & Control & $\begin{array}{c}\mathrm{SAE} \\
(2 \mathrm{mg} / \mathrm{mL})\end{array}$ & $\begin{array}{c}\text { AMP } \\
(1024 \mu \mathrm{g} / \mathrm{mL})\end{array}$ & $\begin{array}{c}\text { SAE +AMP } \\
(0.5 \mathrm{mg} / \mathrm{mL}+4 \mu \mathrm{g} / \mathrm{mL})\end{array}$ \\
\hline \multirow[t]{2}{*}{ PBP2a } & MRSA clinical isolate & ++ & - & +++ & + \\
\hline & ATCC $^{\circledR} 29213$ & ++ & - & +++ & - \\
\hline
\end{tabular}

$\mathrm{SAE}=$ Sauropus androgynus extract, $\mathrm{AMP}=$ Ampicillin, $-=$ Absence/no agglutination, $+=$ weak agglutination, $++=$ Moderate agglutination, $+++=$ Strong agglutination, MRSA=Methicillin-resistant Staphylococcus aureus

Table-4: Potency of SAE, AMP, and SAE+AMP on the ultrastructure of the MRSA's membrane.

\begin{tabular}{|c|c|c|c|c|c|}
\hline \multirow[t]{2}{*}{ Parameters } & \multirow[t]{2}{*}{ Bacterial strain } & \multicolumn{4}{|c|}{ Treatment } \\
\hline & & Control & $\begin{array}{c}\text { SAE } \\
(2 \mathrm{mg} / \mathrm{mL})\end{array}$ & $\begin{array}{c}\text { AMP } \\
(1024 \mu \mathrm{g} / \mathrm{mL})\end{array}$ & $\begin{array}{c}\text { SAE +AMP }(0.5 \mathrm{mg} / \\
\mathrm{mL}+4 \mu \mathrm{g} / \mathrm{mL})\end{array}$ \\
\hline \multirow{4}{*}{$\begin{array}{l}\text { Diameter of } \\
\text { membrane }(\mu \mathrm{m}) \\
\text { Membrane area } \\
\left(\mu \mathrm{m}^{2}\right)\end{array}$} & MRSA clinical isolate & $0.73 \pm 0.01^{\mathrm{a}}$ & $0.87 \pm 0.04^{b}$ & $0.65 \pm 0.02^{c}$ & $0.65 \pm 0.12^{c}$ \\
\hline & ATCC $^{\circledR} 29213$ & $0.76 \pm 0.02^{a}$ & $0.85 \pm 0.05^{b}$ & $0.67 \pm 0.09^{a}$ & $0.61 \pm 0.03^{c}$ \\
\hline & MRSA clinical isolate & $0.54 \pm 0.02^{\mathrm{a}}$ & $0.76 \pm 0.08^{b}$ & $0.43 \pm 0.02^{c}$ & $0.44 \pm 0.17^{c}$ \\
\hline & ATCC $^{\circledR} 29213$ & $0.57 \pm 0.04^{a}$ & $0.73 \pm 0.10^{\mathrm{b}}$ & $0.46 \pm 0.12^{a}$ & $0.37 \pm 0.04^{c}$ \\
\hline
\end{tabular}

$a, b, c$ The different superscript in the same row showed significant differences at $p \leq 0.01$. SAE=Sauropus androgynus extract, $\mathrm{AMP}=$ Ampicillin, MRSA=Methicillin-resistant Staphylococcus aureus

herbal extracts potentially interfere with intracellular mechanisms within bacteria. It may cause an imbalance in the molecular transport mechanism or interfere with membrane permeability of the bacteria. These mechanisms are similar to those achieved by synthetic antibiotics such as AMP. AMP inhibits bacterial growth through its ability to bind to the PBPs produced by bacteria, inhibits transpeptidation reactions, and blocks peptidoglycan synthesis, leading to cell death [18]. However, following the widespread use of AMP in public health services, many pathogens develop resistance to the $\beta$-lactam antibiotics by modifying one or more of those mechanisms [19]. This study demonstrated that MRSA has a high resistance profile against AMP, as reflected by the high concentration of AMP $(1024 \mu \mathrm{g} /$ $\mathrm{mL}$ ) on the inhibition of MRSA growth. Conversely, SAE inhibited MRSA at a concentration of $2 \mathrm{mg} / \mathrm{mL}$, which was similar to that of a previous study [20]. The combination of SAE+AMP induced stronger bacteriostatic activity, which was supported by a decreased concentration of SAE+AMP to $0.5 \mathrm{mg} / \mathrm{mL}+4 \mu \mathrm{g} / \mathrm{mL}$ for MRSA inhibition, respectively.

Furthermore, the synergistic checkerboard test indicated that the SAE+AMP combination was synergic, as shown by the FICI $<0.5$. The synergistic effects of the combination of SAE+AMP were suspected to be caused by several biochemical mechanisms, including the degradation of matrix protein of the bacteria wall and the inhibition of the protein-mediated flux [21]. The combination of SAE+AMP inhibited the synthesis of peptidoglycan that gradually leads to the degradation and depletion of the membrane. Furthermore, the inhibition of protein-mediated flux led to a chaos in the molecular transport system, wherebycarbon, which is potentially required by the bacteria to maintain its existence, was no longer available. The blocking of the molecular transport chain allowed binding of the bacterial membrane and the antimicrobial agents, which inhibited the growth of bacteria in vitro [22]. However, these synergistic mechanisms were not clearly demonstrated in the present study; thus, further investigations including Madin-Darby Canine Kidney testing, pre-clinical animal models, and clinical studies are necessary to fully elucidate the underlying mechanisms involved.

The ability of MRSA to generate penicillin-binding proteins $2 \mathrm{a}$ (PBP2a) was a prominent factor in the increase of MRSA resistance against AMP therapy [23]. The present study showed that the in vitro utilization of AMP against MRSA increased the synthesis of PBP2a semi-quantitatively. Moreover, PBP2a synthesis was increased by MRSA to one level higher than normal conditions without any drug intervention. Following SAE intervention, inhibition of PBP2a synthesis by MRSA occurred in both 
isolates. Surprisingly, the combination of SAE+AMP indicated the effect on PBP2a synthesis by MRSA, and it demonstrated that AMP facilitated the synthesis of PBP2a, albeit at low levels.

The ultrastructural study was conducted using SEM at $10,000 \times$ to evaluate any morphological changes at the cellular level of the MRSA following treatment with AMP, SAE, or its combination. Based on the results, there was a change in the membrane structure in the MRSA after treatment. Morphological changes were induced in the membrane by SAE and SAE+AMP treatment as indicated by the swelling and the contraction of the MRSA membrane, respectively. The area of the membrane of MRSA in both isolates without treatment was between 0.54 and $0.57 \mu \mathrm{m}^{2}$. However, following the administration of SAE, there was an increase in membrane area, and further, a reduction of the membrane area occurred following exposure to SAE+AMP. The cell swelling caused an increase in the membrane area of the MRSA following the utilization of SAE. These effects were due to the chaos of the membrane transport system induced in the bacteria. This ultrastructural study also indicated that SAE and the combination of SAE+AMP generated a disruptive membrane mechanism of the MRSA in vitro. As the most prominent part of the bacteria, its membrane supports the viability of bacteria against extreme environments and any changes in the membrane impacts on the existence of bacteria.

Many studies have shown that herbal remedies have beneficial effects as antioxidant and antimicrobial agents because of the generation of secondary metabolite compounds and its derivatives [24]. This is supported by the present study that showed that the alkaloid, phenolic, glycoside, flavonoid, saponin, and tannin were also components of the SAE. All these compounds are potential antimicrobial agents [25].

MRSA is a Gram-positive bacterium with a thick membrane that consists of lipoprotein and peptidoglycan. Furthermore, the lipoprotein and peptidoglycan within the MRSA membrane facilitate the phenolic components of SAE to induce interactions, leading to changes in osmotic pressure and subsequent membrane disruption. A low osmotic pressure (osmotic downshift) promotes the fluid release from the cytoplasm leads to membrane contraction. Conversely, high ionic pressure promotes the fluid diffusion that causes cell swelling [26]. Furthermore, these mechanisms were also demonstrated in our study. A previous study reported that phenolic compounds decrease the permeability and rigidity of the membrane of Grampositive bacteria [27]. Phenolic compounds also have been shown to bind the cations present on the bacterial membrane and cause an imbalance in the ion charges of the bacteria; furthermore, these mechanisms result in high positive charges that promote the lysis of the membrane [28].

Besides, phenolic compounds, other metabolites of the SAE having potential as antimicrobial agents, are tannin and flavonoids. Tannins can neutralize the lipopolysaccharides within the fibrils and pili of the bacteria, which lead to a weakening of the bacteria to attach on the surface of the host's cells [29]. In addition, flavonoids decrease the fluidity of the MRSA membrane and create hydroxy groups $(-\mathrm{OH})$ during the synthesis of ATP, which cause perforation and decrease the rigidity of the membrane to promote membrane lysis [30].

\section{Conclusion}

This study demonstrated that the SAE exerts potential effects on the growth of MRSA in vitro. Further, the combination of SAE extract and AMP generated synergistic inhibitory effects on PBP2a synthesis and membrane disruption. As a future perspective, herbal medicines should gain more widespread interest in the treatment of microbial resistance because of its potency to restore the susceptibility of bacteria against commercial antibiotics, such as ampicillin.

\section{Authors' Contributions}

AR, CSR, YAP, BUP, and MAM designed the research. YAP analyzed the data and interpretation. YAP, AR, and BUP performed the research. AR, CSR, YAP, MAM, and BUP collaborated during the writing and revising of the manuscripts and approved the manuscript's final version. All authors read and approved the final manuscript.

\section{Acknowledgments}

All the technicians from Integrated Laboratory, the University of Muhammadiyah Sidoarjo and Biological Research Center, Indonesian Institute of Sciences, Bogor, were acknowledged for their support during the study. The authors did not receive any funds for this study.

\section{Data availability}

The datasets used and/or analyzed during the current study are available from the corresponding author on request.

\section{Competing Interests}

The authors declare that they have no competing interests.

\section{Publisher's Note}

Veterinary World (Publisher of International Journal of One Health) remains neutral with regard to jurisdictional claims in published institutional affiliation.

\section{References}

1. Richardson, L.A. (2017) Understanding and overcoming antibiotic resistance. PLoS Biol., 15(8): e2003775.

2. Davies, J. and Davies, D. (2010) Origin and evolution of antibiotic resistance. Microbiol. Mol. Biol. Rev., 74(3): 417-433. 
3. Xu, X., Xu, L., Yuan, G., Wang, Y., Qu, Y. and Zhou, M. (2018) Synergistic combination of two antimicrobial agents closing each other's mutant selection windows to prevent antimicrobial resistance. Sci. Rep., 8: 7237.

4. Ahmed, A., Azim, A., Gurjar, M. and Baronia, A.K. (2014) Current concepts in combination antibiotic therapy for critically ill patients. Indian J. Crit. Care Med., 18(5): 310-314.

5. Kaushik, D., Mohan, M., Borade, D.M. and Swami, O.C. (2014) Ampicillin: Rise fall and resurgence. J. Clin. Diagn. Res., 8(5): ME01-ME03.

6. Golan, Y. (2019) current treatment options for acute skin and skin-structure infections. Clin. Infect. Dis., 68(Supp1 3): s206-s212.

7. Fishovitz, J., Hermoso, J.A., Chang, M. and Mobashery, S. (2014) Penicillin-binding protein $2 \mathrm{a}$ of methicillin-resistant Staphylococcus aureus. IUBMB Life, 66(8): 572-577.

8. Yu, H.H., Kim, K.J., Cha, J.D., Kim, H.K., Lee, Y.E., Choi, N.Y. and You, Y.O. (2005) Antimicrobial activity of berberine alone and in combination with ampicillin or oxacillin against methicillin-resistant Staphylococcus aureus. $J$. Med. Food, 8(4): 454-461.

9. Santiago, C., Pang, E.L., Lim, K.H., Loh, H.S. and Ting, K.N. (2014) Reversal of ampicillin resistance in MRSA via inhibition of penicillin-binding protein 2a by Acalypha wilkesiana. Biomed. Res. Int., 2014: 965348.

10. Bose, R., Kumar, M.S., Manivel, A. and Mohan, S.C. (2018) Chemical constituents of Sauropus androgynus and evaluation of its antioxidant activity. Res. J. Phytochem., 12(1): 7-13.

11. Gayathramma, K., Pavani, K.V. and Raji, R. (2012) Chemical constituents and antimicrobial activities of certain plant parts of Sauropus androgynous L. Int. J. Pharm. Bio Sci., 3(2): 561-566.

12. Wei, L.S., Wee, W., Siong, J.Y.F. and Syamsumir, D.F. (2011) Characterization of antimicrobial, antioxidant, anticancer properties and chemical composition of Sauropus androgynus stem extract. Acta Med. Litu., 18(1): 12-16.

13. Prakoso, Y.A., Kurniasih, K., Wijayanti, A.D. and Kristianingrum, Y.P. (2019) Treatment of experimentally induced diabetic wound infected with methicillin-resistant Staphylococcus aureus using Aloe vera, Apium graveolens, and Sauropus androgynus extracts in rats. Int. J. One Health, 5: 99-106.

14. Albuquerque, B.R., Prieto, M.A., Barreiro, M.F., Rodrigues, A., Curran, T.P., Barros, L. and Ferreira, I.C.F. (2017) Catechin-based extract optimization obtained from Arbutus unedo L. fruits using maceration/microwave/ultrasound extraction techniques. Ind. Crops Prod., 95: 404-415.

15. Ajuru, M.G., Williams, L.F. and Ajuru, G. (2017) Qualitative and quantitative phytochemical screening of some plants used in ethnomedicine in the Niger Delta region of Nigeria. J. Food Nutr. Sci., 5(5): 198-205.

16. Teethaisong, Y., Autarkool, N., Sirichaiwetchakoon, K., Krubphachaya, P., Kupittayanant, S. and Eumkeb, G. (2014) Synergistic activity and mechanism of action of Stephania suberosa Forman extract and ampicillin combination against ampicillin-resistant Staphylococcus aureus. J. Biomed. Sci., 21(1): 90.

17. Orhan, G., Bayram, A., Zer, Y. and Balci, I. (2005) Synergy test by $\mathrm{E}$ test and checkerboard methods of antimicrobial combination against Brucella melitensis. J. Clin. Microbiol., 43(1): 140-143.
18. Chudobova, D., Dostalova, S., Blazkova, I., Michalek, P., Ruttkay-Nedecky, B., Sklenar, M., Nejdl, L., Gumulec, J., Tmejova, K., Konecna, M., Vaculovicova, M., Hynek, D., Masarik, M., Kynicky, J., Kizek, R. and Adam, V. (2014) Effects of ampicillin, streptomycin, penicillin and tetracycline on metal resistant and non resistant Staphylococcus aureus. Int. J. Environ. Res. Public Health, 11(3): 3233-3255.

19. Chan, L.C., Gilbert, A., Basuino, L., Da Costa, T.M., Hamilton, S.M., Dos Santos, K.R., Chambers, H.F. and Chatterjee, S.S. (2016) PBP 4 mediates high level resistance to new generation cephalosporins in Staphylococcus aureus. Antimicrob. Agents Chemother., 60(7): 3934-3941.

20. Prakoso, Y.A., Kurniasih, Wijayanti, A.D. and Kristianingrum, Y.P. (2019) Activity of Aloe vera, Apium graveolens and Sauropus androgynus alcoholic extracts against methicillin-resistant Staphylococcus aureus. World Vet. J., 9(4): 302-310.

21. Brantley, S.J., Argikar, A.A., Lin, Y.S., Nagar, S. and Paine, M.F. (2014) Herb drug interactions: Challenges and opportunities for improved predictions. Drug Metab. Dispos., 42(3): 301-317.

22. Buss, J.A., Baidin, V., Welsh, M.A., Flores-Kim, J., Cho, H., Wood, B.M., Uehara, T., Walker, S., Kahne, D. and Bernhardt, T.G. (2019) Pathway directed screen for inhibitors of bacteria cell elongation machinery. Antimicrob. Agents Chemother, 63(1): e01530-18.

23. Santiago, C., Lim, K.H., Loh, H.S. and Ting, K.N. (2015) Prevention of cell-surface attachment and reduction of penicillin-binding protein 2a (PBP2a) level in methicillin-resistant Staphylococcus aureus biofilms by Acalypha wilkesiana. BMC Complement. Altern. Med., 15: 79.

24. Lelario, F., Scrano, L., De Franchi, S., Bonomo, M.G., Salzano, G., Milan, S., Milella, L. and Bufo, S.A. (2018) Identification and antimicrobial activity of most representative secondary metabolites from different plant species. Chem. Biol. Technol. Agric., 5(13): 1-12.

25. Uche-Okereafor, N., Sebalo, T., Tapfuma, K., Mekuto, L., Green, E. and Mavumengwana, V. (2019) Antibacterial activities of crude secondary metabolite extract from Pantoea species obtained from the stem of Solanum mauritianum and their effects on two cancer cell lines. Int. J. Environ. Res. Public Health, 16(602): 1-12.

26. Wood, J.M. (2015) Bacterial response to osmotic challenges. J. Gen. Physiol., 145(5): 381-388.

27. Wu, Y., Bai, J., Zhong, K., Huang, Y., Qi, H., Jiang, Y. and Gao, H. (2016) Antibacterial activity and membrane-disruptive mechanism of 3-p-trans-coumaroyl-2-hydroxyquinic acid, a novel phenolic compound from pine needles of Cedrus deodara, against Staphylococcus aureus. Molecules, 21(1084): 2-12.

28. Malanovic, N. and Lohner, K. (2016) Gram-positive bacterial cell envelopes: The impact on the activity of antimicrobial peptides. Biochim. Biophys. Acta, 1858(5): 936-946.

29. Soriani, M. and Telford, J.L. (2010) Relevance of pili in pathogenic streptococci pathogenesis and vaccine development. Future Microbiol., 5(5): 735-747.

30. Farkas, A., Maroti, G., Kereszt, A. and Kondorosi, E. (2017) Comparative analysis of bacterial membrane disruption effects of two natural plant antimicrobial peptides. Front. Microbiol., 8(51): 1-12. 